старший викладач Інституту іноземних мов Дрогобицького державного педагогічного університету імені Івана Франка

\title{
А. ШТІФТЕР: ОСОБЛИВОСТІ НОВЕЛІСТИЧНОЇ КОМПОЗИЦІї ТВОРІВ
}

У статті проаналізовано особливості новелістичної композичії творів австрійського письменника А. Штіфтера. Розглядається художня структура та специфіка новел та оповідань прозаїка.

Ключові слова: бідермаєр, творчість, новела, пейзаж, розповідь, письменник.

В статье проанализированы особенности новеллистической композиции произведений австрийского писателя А. Штифтера. Рассматривается художественная структура и специфика новелл и рассказов прозаика.

Ключевие слова: бидермаейер, творчество, новелла, пейзаж, рассказ, писатель.

The features of novelistic composition in the works of Austrian writer A. Shtifter are analyzed in the article. Shtifter was called an Austrian contemporary of literary prose, as his work accounts to the first half of the XIX century. The artistic structure and specificity of novels and short stories of writer is considered.

Key word: biedermeier, creation, novel, landscape, story, writer.

Період творчості видатного австрійського прозаїка Адальберта Штіфтера припадає на 40-ві роки XIX століття. Творчість письменника як хронологічно так і тематично відноситься до течії бідермаєр. Саме поезія Штіфтера знаменує початок становлення австрійської прози, яка співпала 3 розповсюдженням бідермаєра як течії в літературі.

Новелістика Штіфтера пізнього періоду виявляє численні закономірності зв’язку і конотації з його ранніми творами. Так мотиви «Лісового струмка» (Der Waldbrunnen, 1866) зустрічалися ще в новелі «Котяче срібло» (Das Katzensilber, 1847). Саме там була зображена прекрасна, непокірна, таємничо зникла дівчинка. Героїня отримує ім'я Юліана, так як звали і прийомну дочку сім’ї Штіфтер, яка трагічно загинла у віці вісімнадцяти років (дівчина йде $з$ дому, згодом іï тіло знаходять в Дунаї). Новели Штіфтера 3 усією очевидністю переходять безпосередньо і до автобіографічних подій творчого шляху Штіфтера. Новела «Лісовий струмок» містить в зв'язку з цими обставинами спробу автора осмислити все, що відбулося і виправити стан речей хоча б в 
ідеальному світі, існування якого цілком можливо в творчій уяві письменника. У тексті йдеться про виправлення характеру «дикої дівчинки», поступовому $\mathrm{i}$ терплячому iï вихованні. Ідея виховання, на перший погляд, здається основоположною для даного твору. Однак зміст ії в дійсності набагато глибший та складніший, ніж вираз ідеї про виправлення людини за допомогою освіти [Штіфтер 1959:625].

Зав’язка новели і подальший розвиток мотивів вказує на те, що Штіфтер намагається вирішити для себе ірраціональну таємницю краси. 3 самого початку, як типово для Штіфтера, представлені якісь натяки на таємницю, пов'язану $з$ красою двох жінок, юної «циганки», увійшовшої випадково на сільський майдан Нойкірхен, і «брюнетки» (eine schwarze Frau), що вразила уяву оповідача в юності. Разом з тим підкреслено ту обставину, що це не просто земна краса, це в чомусь втілення небесного ідеалу. Ідеальне сприйняття краси оповідачем коригується далі в тексті жартівливим зауваженням його дружини, що він «знаходить свої божественні зразки краси тільки у таких жінках, колір обличчя яких нагадує не зовсім новий церковний дзвін [Müller 1961:87].

Рамка, встановлена в тексті введенням фігури оповідача (розповідь йде від першої особи), розширюється і вміщує історію якогось Стефана Хайлькуна, літнього пана, який подорожує разом 3 онуками. Як і багатьом іншим персонажам Штіфтера, йому притаманний особливий «осінній» стан, який так точно помітив і визначив К. Магріс. Світла туга за минулим з'єднується в його душі з глибоко прихованою спрагою любові і щастя. Навколишній природний світ дозволяє сублімувати мрію, замінити ії міцністю і незмінністю ландшафту. Ліс постає як набуття щастя, яким він хотів би поділитися з онуками. Слід підкреслити, що пейзажі Штіфтера мають найчастіше преспективу віддаленості: ліс, розглянутий десь на обрії, ландшафт, що відкривається з вікна і теж досить віддалений, або нерідко спостерігається з висоти гір. Цей ракурс викликає враження, як уже було зазначено вище, нечіткості ліній, їх розмитості, розчинення речей і предметів в «блакитну» далечінь [Hunter 1972:119-123]. 
В. Мушг вказує, що улюбленим кольором Штіфтера стає згодом сірий: вишукані сукні героїнь, стіни замків як жител так і сховищ сімейних таємниць (сірий Сентце, сірі стіни фортеці Ротенштейн), блакить гір, що переходить в сіре забарвлення квітів, пір'я птахів, гілки дерев, горіхи - все це збирає героїня, дивна дівчинка, з якою знайомляться діти і Хайлькун [Muschs 1965:190]. Ці предмети позначені Штіфтером як несучі знакове навантаження. Вони пов'язують світ напівбожевільної дівчинки зі світом iï старої бабусі, якій вона приносить їх в дар. Вибудовується ланцюг значень, що ведуть до основної метафори: дівчинка пов'язана зі своїм праобразом, бабусею, яка представляє на знаковому рівні вічний початок жіночності, ірраціональності та незбагненності. У сюжет вводиться далі і цитування віршів Гете і Шіллера (вони не просто цитуються, вони вигукували або співаються дівчинкою на камені, що стоїть посеред джерела). Юліана вигукує вірш Гете: «Heiss mich nicht reden, heiss mich nicht schweigen ...». У тексті з'являється саме Гетевська ремінісценція: Юліана пізнає перші уроки освіти, еволюціонує у душі та свідомості [Stifter 1959:625].

Важливим завершенням сюжету $\epsilon$ епізод усвідомлення літнім паном Хайлькуном щирої та самовідданої любові Юліани. Протагоніст постає як людина, яка вперше усвідомила штучність i, мабуть, прагматичність, в якійсь мірі, відносин, з якими він був пов'язаний в суспільстві, і який відкрив глибину і зворушливість чистого почуття. Далі в тексті виникає мотив зв'язку поколінь, які можуть бути об’єднані любов'ю. Бабуся сидить, гріючись на сонечку в очікуванні приходу Стефана Хайлькуна, так, як ніби «вона чекала нареченого». Юліану беруть в його сім'ю, щоб вона змогла отримати належне виховання, щоб в подальшому вона змогла стати гідним іï членом. Розв'язка характерна для бідермаєрської новели: всі щасливі, загадка зустрічей дозволена. «Брюнетка», що вразила своєю незвичайною красою оповідача, виявляється тією самою «дикою дівчинкою» Юліаною, важливий вплив на розвиток дівчини сприяв колись не дуже щасливий у своєму особистому житті Стефан Хайлькун. Таким чином, не зумівши подолати тяжіння виховання прийомної дочки в 
реальному житті, Штіфтер переносить проблему в ідеальний світ, висловлюючи багато в чому абстрактну надію на добрий початок людини.

Розповідь «Поцілунок роду Сентце» (Der Kuss von Sentze, 1866) тематично повязаний з більш раннім твором «Стара печатка». Тут зображений аристократичний рід, близький до занепаду і так само підніметься питання про примирення людей на основі морального закону. У текст вводиться мотив обітниці. Однак, якщо в ранньому творі він набував негативного висвітлення, то в оповіданні «Поцілунок роду Сентце» дотримання заповіданих правил ставало умовою стабільності подальшого існування сім’ї. Мотив поцілунку, коннотативно повязаний з біблійним текстом як ілюзія (поцілунок Іуди). Один iз засновників роду Сентце заповідав своїм нащадкам, щоб не множити зла «в світі», в знак примирення цілуються, але не зрадницьким поцілунком Іуди [Arts 1976:262].

Акціональний ланцюг розгортається далі таким чином, що два останніх нащадка старої сім’ї, Руперт і Хільтібург, повинні одружитись для продовження роду. Однак якщо це буде неможливо, потрібно обмінятися поцілунком роду Сентце, щоб надалі не завдавати один одному шкоди і зла. Просте та частково банальне мотивування розвивається далі, в тексті виникає ретардація, характерна для пізнього стилю Штіфтера. Здавалося б, кульмінаційне завершення міститься в епізоді, коли горда i неприступна світська красуня Хільтібург все-таки цілує Рутгера перед від’їздом на війну. Однак виникає ретардаційне застереження, герой нібито не дізнається про улюблену ним дівчину. Сюжетна напруга слабшає, починається опис, що стосується перебування Рутгера в гостях у Валькона, батька Хільтібург. I тут на передній план виступає традиційний мотив будинку. У цьому оповіданні мотив будинку має такі функції. По-перше, він $\epsilon$ антитезою хаосу і ворожості світу. По-друге, мотив будинку має в даному тексті значення «примноження» i, таким чином, виходу в світ, прилучення до людей i до навколишнього середовища. По-третє, будинок асоціюється 3 місцем якоїсь урочистої дії, ритуалу, так велично буденне протягом часу в ньому. Урочистість перебування в будинку 
гостя підкреслена деталізацією подій і їх розподілом за часом: переодягання в більш святковий одяг, запрошення сісти поруч, згадка, що сам господар сів 3 лівого боку, вказівка на часовий проміжок. По-четверте, будинок як місце спокою, стабільності і тиші, має в своєму розпорядженні заняття більш важливіше i значніше по відношенню до буття і природи. Колекціонування мохів стає тут також діянням «примноження», збирання, накопичення знань про світ. Будинок і в цьому своєму значенні пов’язаний із зовнішнім світом. Колекціонування, вивчення через нього природи, в свою чергу, рятує від розчарування і ілюзорності життя.

Новим важливим моментом, провідним вже до розв'язки в сюжеті, стає повернення Хільтібург до свого батька. Відбувається зустріч героїв, і щаслива розв'язка обумовлена змінами, що відбулися в зовнішньому вигляді $і$ в характері героїні. Вона повертається від світського життя Відня до природного буття на лоні природи і в родині. Деталі (одяг сірого кольору, такого ж, як одяг iii батька, солом’яний капелюх, шкіряна сумка на плечі, міцні чобітки для ходіння в ліс) підкреслюють зміну, що відбулася 3 героїнею, що блищала колись своїм багатим одягом. Поцілунок, який скріпив союз закоханих, є новим заключним епізодом, який веде до розв'язки розповіді: Руперт остаточно переконується в тому, що його колись поцілувала саме Хільтібург. Поцілунок стає не тільки обітницею, яку повинні виконати останні нащадки роду, а й справжнім знаком любові. I якщо в ранній новелі «Безглуздий замок» дворянський рід остаточно йде з історичної сцени і гине, а замок перебудовує їх дуже віддалений родич-бюргер, то в уже згадуваному тексті щасливим чином всі будівлі роду об'єднуються в одну родину, що $є$ також знаком не тільки добробуту, а й ідеального любовного союзу. У своїх останніх оповіданнях, таким чином, Штіфтер також схильний до створення ідеалізованої утопії, яка була характерна i для роману «Бабине літо». Відомо, що розповідь була спочатку відхилена видавцем журналу «Книга світу» (Das Buch der Welt) А. Гофманом в Штутгарті і надрукована лише в «Австрійськії альтанці» (Die Gartenlaube für Österreich). Для 60-х років XIX століття цей літературний твір 
Штіфтера здавався вже анахронізмом, недоречним напередодні нових літературних віянь і течій.

Типовим зразком пізньої творчості А. Штіфтера можна вважати також одне з його останніх оповідань «Святий вислів» (Der fromme Spruch, 1867). Як у багатьох попередніх творах письменник звертається до теми сім’ї, любові, зв’язку поколінь. Він буквально «заклинає» в творах 60-х років міцність і святість сімейних зв’язків, нерозривність поколінь. Слід підкреслити, що твір відхилив також видавець журналу «Katholische Welt» Лео Тепе під приводом гострої критики з боку рецензентів. У листі до Шітфтера він писав: «Розповідь неприродна; таких одервеневшіх людей не існує, їхні мови немов загвинчені болтами (wie auf Schrauben gestellt); повсякденні речі показані в нескінченній розтягнутості; дію майже зведено нанівець, стиль натягнутий i сповнений протиріччями; навряд чи можна вважати, що автор серйозний, іноді схиляєшся до того, щоб прийняти всіх за карикатуру неаристократичної сім’ї».

У перерахуванні «недоліків» творів Штіфтера критиком висловлено, саме, бажання бачити зовсім іншу літературу, засновану на правдоподібності, психологізмі, сюжетному розгортанні дії, літератури, що відповідає запитам читачів 60-х років ХІХ століття. Сам Тепе пояснював «невдалу» розповідь тим, що вона за стилем нагадувала «Вітіко». Однак для читача цей стиль здавався чимось «чужим і смішним». Штіфтер виправдовувався, що його просто не зрозуміли і що він зовсім не хотів зобразити дворянство в карикатурному світлі.

Споріднені та сімейні зв’язки сплітаються в «Святому вислові» в якийсь загадковий вузол. Зав'язка оповідання пов'язана 3 урочистою та радісною подією в старовинній аристократичній родині фон дер Вайден: холостяк Дітвін, якому виповнюється п’ятдесят років, приїжджає привітати 3 днем народження свою сорокачотирирічну сестру Герлінт. Урочистість відбувається в піднесеному стилі, який містить повтори синтаксичних оборотів, які лунають як для 1860 року дещо архаїчно. Урочисто зображена саме колірна гамма подій. Герлінт в «платті з чорного шовку», іiї камеристка «також ... в чорному шовку», «блідо-рожевий оксамит» шкатулки, на якому лежить «бездоганний перли», 
«розкішний килим на мармуровій підлозі», «вишивка по білому шовку золотом ... ». Як щось дуже значне і піднесене зображені дари (саме так сприймають подаровані один одному речі Дітвін і Герлінт). Не змовляючись, брат і сестра дарують перли. Символіка відбувається, як це характерно для пізнього стилю Штіфтера, проста i банальна. Адже перли покликані підкреслити красу і чистоту помислів брата і сестри. Зав’язкою ж дії є бажання героїв поєднати шлюбом своїх племінників, що носять ті ж самі імена, що і їх опікуни Дітвін і Герлінт. У структурі розповіді намічене певне коло, яке повинне з'єднати сім’ю заново, скріпивши цей шлюб спільним володінням маєтків і майна, про що не забуває згадати герой оповідання Дітвін. Це коло повинне замкнутися, таким чином, не тільки любов’ю і створенням сім'ї, але і просторовими межами володінь фон дер Вайден. Композиція твору має тенденцію, таким чином, стати кільцевою. Типово бідермаєрська референція ускладнюється елементами психологізму. 3'ясовується, що юні Дітвін і Герлінт мають горді та непокірні характери, які вони проявляли досить жорстко вже в дитинстві: хлопчик бив свою юну родичку, а дівчинка якось завдала йому рану ножем.

У штучно створеній ситуації знайомства i зближення в будинку тітки герої проявляють все ті ж характерні для них риси. Саме епізод у вирощуванні ними троянд можна інтерпретувати в декількох значеннях. По-перше, розведення троянд в саду, очевидно, стає метафорою виховання та прищеплення любові один до одного самих героїв. По-друге, троянди можуть боляче вколоти, незважаючи на свою красу, герої подібно трояндам, наносять уколи самолюбству один одного. По-третє, не випадкові зауваження дядька, що незабаром його юні племінники в своїй ретельності заповнять трояндами весь простір між двома замками. В його словах - надія на створення нової сім’ї та зміцнення традицій роду. Таким чином, троянда як символічний елемент оповіді, виконує безліч функцій, як це було властиво і для роману «Бабине літо». 
Поворотним моментом в структурі розповіді можна вважати епізод, коли опікуни юної пари раптом несподівано виявляють, що Дітвін і Герлінт не тільки не виявляють зацікавленості один в одного, але, більш того, захоплені своїми родичами. У текст введений мотив ідеального праобразу любові і мрії, тому що герої довго не відходять від мальовничих зображень своїх тітки і дядька. Однак розумні і виховані старші Дітвін і Герлінт, приголомшені своїм відкриттям. Вони не стільки відкидають можливість подружньої любові з боку своїх юних родичів, скільки визнають існування сформованих умовностей. Перш за все, вік обох сторін завадив би їм вступити в шлюб. Загроза неконтрольованих почуттів i їх стихійних проявів зникає так само несподівано, як вона і була раптово відкрита. Повідомивши юним Дітвіну і Герлінт про свій можливий від’їзд, тітка і дядько раптом чують від юної пари рішення вступити в шлюб. У текст вводиться мотив «не відбування подорожі». Його відміна пов'язана тут 3 подією більш значною.

Цей текст Штіфтера має також педагогічну спрямованість і відображає погляди самого Штіфтера на виховання людини. Явно авторські погляди висловлює один 3 протаганістів, Дітвін-старший. На його думку, людина має в своєму житті три фази розвитку. У першій фазі бере верх гарячковість, потім приходять різні фантазії, і тільки потім виявляються лагідність і сердечність, які тривають до похилого віку. Племінники, на думку старших, знаходяться десь між першою і другою фазою розвитку, і тільки з укладенням шлюбу вони здатні перейти в третю, яка визначила б їх подальше життя. Крім цього «трьохфазового» розвитку людини, погляди автора, висловлені в даній новелі, припускають простоту дійсності життя молодої людини [Stifter 1969:677].

Розповідь нагадує структурно також ранні твори Штіфтера. Незважаючи на ретардацію дій, вона поділяється на три рівномірні за обсягом частини. У першій з них - зав'язка сюжету. У другій - його розвиток з гостро драматичним зображенням епізоду (демонстрація прекрасних троянд в маєтку Дітвіна, що припускає суперництво і небажання підкоритися волі іншого з боку юної пари). У третій - кульмінаційний момент, що наближує розв'язку, коли з'ясовується, 
що молоді люди люблять своїх опікунів. Тут же щаслива розв’язка і пов’язане 3 нею підкреслення урочистості і значущості моменту, що проявляється, перш за все, в мові персонажів. Новелістична структура в даному випадку «розпушується» надмірністю самого тексту, його простір розширюється, вміщуючи описові елементи. Вживання архаїчної лексики (чоловік, дружина, вельмишановний, борг шлюбу), синтаксична ускладненість пропозицій 3 періодичністю звучання одних $\mathrm{i}$ тих самих слів створюють типово «штіфтерський» ритм тексту. Подія відбулася, укладений шлюб, і в кінці знову повторюється рефрен всього тексту «Шлюби укладаються на небесах». Однак слід підкреслити, що значення цього прислів’я в рамках тексту уточнюється i конкретизується. Повторюючи цей вислів, старше покоління все робить для того, щоб допомогти небесам в цьому діянні. Звідси випливає конкретизація даного прислів’я іншому - «Допоможи Богу сам, щоб він допоміг тобі». Штіфтер висловлює, таким чином, характерну бюргерську позицію, що виражається не в очікуванні звершення волі небес, а в активності самих людей, що сприяють своєму щастю. I в цьому він проявляється також як типовий автор бідермаєра.

Отже, в творах раннього періоду відбувається відступ від традиційної новели, хоча до ряду творів можна застосувати зазначений термін: «небачена подія», що стоїть в центрі новелістичної оповіді, яка в творах Штіфтера знімає свою гостроту, та стає частиною повсякденної та сімейної тематики бідермаєра; зовні романтичний конфлікт ранніх новел поступово поступається місцем зображенню душевного переживання. А для пізніх творів Штіфтера характерні такі структурні риси, як ретардація сюжетної дії, «множення» кількісного в зображенні побуту і навколишнього світу, архаїчна урочистість в показі самих повсякденних «картин» і образів. Ці твори Штіфтера скоріш можна назвати в силу таких властивостей, як ретардация сюжету, відсутність новелістичної напруженості, розповідями. 


\section{БІБЛІОГРАФІЯ}

Михайлов 1997 - Михайлов А. В. Проблемы анализа перехода к реализму в литературе X1X века / А. В. Михайлов // Языки культуры. М., 1997. C. $43-111$.

Полубояринова 1990 - Полубояринова Л. Н. Позднее творчество Адальберта Штифтера: дисс. ... канд. филол. наук. - Ленинград, 1990. - 280 с.

Штифтер 1971 - Штифтер А. Лесная тропа. Повести и расказы. пер. с нем. [Сост. и вступит. статья С. 3 - 26. С. Шлапоберской]. - М. : «Худож. лит.», 1971. -519 c.

Arts 1976 - Arts Eva. Studien zur Erzählkunst Adalbert Stifters. Der Aufbau der vier späten Erzählungen. - Wien: VWGÖ, 1976. - S. 262.

Hunter 1972 - Hunter R. Ist der Rahmen des -Waldbrunnen überflüssig? Einige Bemerkungen zu Stifters Späterzählung // Vierteljahresschrift / AdalbertStifter-Institut des Landes Oberösterreich. - 1972 - 21. - S. 119-123.

Klein 1956 - Klein J. Geschichte der deutschen Novelle von Goethe bis zur Gegenwart / 3. verbesserte und erweiterte Auflage. - Wiesbaden: F. Steiner, 1956. S. 198.

Magris 2000 - Magris C. Der habsburgische Mythos in der modernen österreichischen Literatur. Wien: P. Zsolnay Verl., 2000. - 414 s.

Muschg 1965 - Muschg W. Das Farbenspiel von Stifters Melancholie // Studien zur tragischen Literaturgeschichte. Bern und München: Francke Verl., 1965. - S. 190.

Müller J. Novelle und Erzählung // Etudes Germaniqes. - Paris -1961 -16. Jg. - Nr. 2. - S. 87.

Stifter - Stifter A. Der fromme Spruch / Stifter A. Bunte Steine und Erzählungen. - S. 677.

Stifter 1959 - Stifter A. Gesammelte Werke. In 6 Bd. Sechster Bd: Kleine Geschichte. - Wiesbaden: Insel Verl., 1959. - 614 s.

Stifter 1979 - Stifter A. Studien / Mit einem Nachwort von F. Krökel und Anmerkungen von K. Pörnbacher. - München: Winkler Verl., 1979 - 1234 s. 